\title{
Performance of self-compacting concrete containing hybrid fibers in aggressive environment
}

\author{
Mohammed Salman ${ }^{1}$, Qais Frayyeh ${ }^{2 *}$, Luma Zghair ${ }^{1}$ \\ ${ }^{1}$ Civil Engineering Department, Al- Mustansiriyah University, Baghdad, Iraq \\ ${ }^{2}$ University of Technology, Baghdad, Iraq
}

\begin{abstract}
Self-compacting concrete can be used in many concrete applications some of it susceptible to acid attacks. The aims of this study are to investigate the resistance of different SCC mixture designs to sulphuric acid attacks. The test variables included the type of hybrid fibers (steel, plastic and polypropylene fibers). The powder content of the mixes was kept constant. (500) Kg/m3. The slump flow, L-box, and Vfunnel were performed for mixes in their fresh state. In the present work, the specimens were immersion in sulphuric acid solution at concentration of $(0.5 \%)$ up to 289 days after normal curing for 28 days. After concrete has hardened, two types of test are performed before and after immersion in sulphuric acid solution. Firstly destructive tests are conducted including (compressive strength, splitting tensile strength, and modulus of rupture). Secondly non-destructive tests are performed including (mass loss). The result obtained from this work, shows that the use of hybrid fiber was significant in improving the resistance to sulphuric acid solution in the case of splitting tensile strength, mass loss and modulus of rupture on the other hand, the use of hybrid fibers was insignificant in reducing the concrete compressive strength loss.
\end{abstract}

Index Terms - self-compacting concrete, hybrid fibers, sulfuric acid

\section{INTRODUCTION}

Deterioration of concrete members prone to aggressive acid environments are durability issue that affects the life cycle performance and maintenance of infrastructure.[1] Concrete can be attacked by liquids with $\mathrm{pH}$ value below 6.5 but the attacks are severe only at a pH below 5.5 [2] Sulfuric acid fluids are classified as the most aggressive of natural threats to concrete structures. Generally, they arise from industrial operations, but they can be caused by urban area activities. Large amount of acids exist in sewage systems. Acid attack is influenced by the processes of disintegration and leaching of cement paste constituent. A very important quantity of admixtures in SCC paste can negatively or positively affect its resistance to acid aggression. [3] .The deterioration of concrete in acidic environments is influenced by several factors such as the type of cement used, permeability of concrete, and the surrounding environmental conditions. Furthermore, the solubility of calcium salt produced from the acid - base reaction of the cementitious paste and attacking acid is an important factor. [4] Many studies about the performance of concrete exposed to sulphuric acid solution have been completed.

An experimental program was carried out by Senhadjiet al. [5] to study the influence of different supplementary cementitious materials (silica fume, natural pozzolan) and limestone fine at various replacement levels. The results showed that the addition of limestone powder or natural pozzolan can improve the acid resistance of mortar, but at different rates depending on the proportion of supplementary cementitious materials. On the other hand, mortars with silica fume are seriously damaged in the sulphuric acid environment. They reported that despite the improving SF the compressive strength and reduced the porosity of concrete, this improvement was not effective for enhancing the resistance of concrete to sulphuric acid attacks. In other words, converting $\mathrm{C}-\mathrm{H}$ into calcium silicate hydrate and refining the porosity of concrete did not improve its resistance to severe sulphuric acid attacks. They also reported that C-S-H which formed from pozolana reaction may be chemically unstable in acidic environments.

Fan et al .[6] estimated the tensile properties of normal concrete $\left(283 \mathrm{~kg} / \mathrm{m}^{3}\right.$ cement) exposed to acid rain, in this study the $\mathrm{pH}$ level of acid rain was below 5.6. Based on the test result the following was observed

At the initial damage stage, both the elastic modulus and the tensile strength of the concrete samples exhibit a slight increase. When the damage continues, the tensile strength and the elastic modulus of the specimen gradually decrease after 70 days immersion in acid solution.

Bassuoni and Nehdi[1] examined the resistance to sulfuric acid solutions ( $\mathrm{pH}$ of 2.5 and 1.0) of a different

*Corresponding author: jwd ks@yahoo.com 
range of SCC mixtures containing cement only or cement with different pozolana material (silica (fume, slag and fly ash) with or without hybrid fiber reinforcement macro steel + micro polypropylene). The results indicated that:

1. The resistance of SCC to aggressive sulfuric acid solution was improved using binder with pozolana.

2. Using hybrid micro - and macro - fibers can be effective in retaining the cementitous matrix integrity and controlling disruptive pressures resulting from voluminous reaction product. Saleh et al. [7] used different types of fibers (carbon and polypropylene) to minimize the corrosive action of sulfuric acid solution on concrete industrial water tanks. Compressive strength test, ultrasonic pulse velocity, bulk density, and water absorption tests were done to the samples after curing in normal water for $(7,28,60,90,180)$ days and then they were exposed to dilute sulfuric acid solution $(10 \%$ concentration) for $(7,30,60,90,180)$ days. The results indicate that using carbon fibers was more effective for enhancing the resistance of concrete to sulphuric acid attacks.

\section{Research significant}

Several concrete elements are susceptible to chemical attacks of sulfuric acid, including, industrial floors of chemical plants, superstructures, sewage pipe systems, etc., even though there has been an increased use of SCC in many concrete applications, a comprehensive review of literature indicates that there is lack of information on the role of hybrid fibers, which can be inserted in SCC in such aggressive environment.

\section{Materials}

The binders used included ordinary Portland cement (OPC), (ASTM C150 - Type 1) [8]. The cement was tested and checked according to IQS 5:1984[9], silica fume (SF) of class Npozzolans (ASTM 618-03)[10], limestone powder (chalk powder) was used throughout this investigation. Table (1) shows the chemical and physical properties for the various binders.

Three types of fibers were used for the purpose of this study. These types are steel, plastic and polypropylene fibers. Table (2) illustrates the properties of these fibers. The binder content was kept constant at $500 \mathrm{~kg} / \mathrm{m}^{3}$ compatible to the guidelines for SCC mixture design [e.g. EFNARC] [11]. The fine aggregate has a fineness modulus of 2.6, and specific gravity of 2.65. The maximum nominal size for crushed coarse aggregate was $10 \mathrm{~mm}$, with a specific gravity of 2.62 . The constituents of the selected SCC mixes are given in Table 3.
Table 1 . The chemical and physical properties for the various binders

\begin{tabular}{|c|c|c|c|}
\hline Oxides & Cement & $\begin{array}{c}\text { Silica } \\
\text { fume }\end{array}$ & $\begin{array}{c}\text { Chalk } \\
\text { powder }\end{array}$ \\
\hline $\mathrm{SiO}_{2}$ & 20 & 96.68 & 2.24 \\
\hline $\mathrm{Fe}_{2} \mathrm{O}_{3}$ & 3.9 & 0.069 & 0.12 \\
\hline $\mathrm{Al}_{2} \mathrm{O}_{3}$ & 4.5 & 0.20 & 0.42 \\
\hline $\mathrm{CaO}$ & 62 & 0.54 & 68.73 \\
\hline $\mathrm{MgO}$ & 2.43 & 0.12 & 0.70 \\
\hline $\mathrm{SO}_{3}$ & 2.03 & 0.61 & $<0.07$ \\
\hline specific gravity & 3.2 & 2.13 & 2.42 \\
\hline $\begin{array}{c}\text { specific surface area } \\
\mathrm{m}^{2} / \mathrm{g}\end{array}$ & 4.37 & 0.157 & 3.17 \\
\hline
\end{tabular}

Table 2 . Properties of fibers

\begin{tabular}{|c|c|c|c|}
\hline Types of fiber & Plastic & $\begin{array}{c}\text { Poly } \\
\text { propylene }\end{array}$ & $\begin{array}{c}\text { Micro } \\
\text { steel }\end{array}$ \\
\hline Description & crimped & monofilament & straight \\
\hline $\begin{array}{c}\text { Length of } \\
\text { fiber (mm) }\end{array}$ & $30 \mathrm{~mm}$ & 12 & 15 \\
\hline $\begin{array}{c}\text { Tensile } \\
\text { strength (MPa }\end{array}$ & $250-300$ & 350 & 2600 \\
\hline Aspect Ratio & 63 & 66.7 & 75 \\
\hline
\end{tabular}

Table 3 . The constituent of the selected SCC mixes

\begin{tabular}{|c|r|r|r|r|}
\hline \multirow{2}{*}{ Mix notation } & \multirow{2}{*}{ SP\% } & \multicolumn{3}{|c|}{ Fibers by volume \% } \\
\cline { 3 - 5 } & & Steel & plastic & $\begin{array}{r}\text { Polypropylen } \\
\mathrm{e}\end{array}$ \\
\hline SCC LP SF & 8.7 & - & & 0.2 \\
\hline $\begin{array}{c}\text { SCC SF LP } \\
\text { SFHR1 }\end{array}$ & 11 & 0.3 & - & - \\
\hline $\begin{array}{c}\text { SCC SF LP } \\
\text { SFHR2 }\end{array}$ & 13 & 0.3 & 0.2 & \\
\hline
\end{tabular}

Note: for all mixes: water $=1701 / \mathrm{m}^{3}$, sand $=778 \mathrm{~kg} / \mathrm{m}^{3}$, gravel $=890$ $\mathrm{kg} / \mathrm{m}^{3}$, limestone powder $=150 \mathrm{~kg} / \mathrm{m}^{3}$, cement $=315 \mathrm{~kg} / \mathrm{m}^{3}$ and silica fume $=35 \mathrm{~kg} / \mathrm{m}^{3}$

To improve flowability of the SCC mixtures, copolymerbased Superplasticizer, (SP) designed for the production of SCC (Glenium 51) with relative density of 1.1 at $20^{\circ} \mathrm{C}$ was incorporated in all mixtures. The dosages of SP was modified to maintain a slump flow of $600-750 \mathrm{~mm}$, T50 (4 to 10) sec., L box index (>0.75) (3 Ǿ10 mm with 50 $\mathrm{mm}$ gaps) and $\mathrm{V}$-funnel flow (3 to 25 ) sec. The fresh properties were evaluated and compared with EFNARC] [11] and the European Guidelines for SCC [12]. The result of fresh properties of SCC mixtures are summarized within Table 4. 
Table 4. Fresh properties of concrete mixtures

\begin{tabular}{|c|c|c|c|c|c|}
\hline $\begin{array}{c}\text { Mix } \\
\text { notation }\end{array}$ & $\begin{array}{c}\text { Slump } \\
\text { depression } \\
\mathrm{mm}\end{array}$ & $\begin{array}{c}\text { T50 } \\
\text { Sec. }\end{array}$ & $\begin{array}{c}\text { L-box } \\
\text { index }\end{array}$ & $\begin{array}{c}\text { V- } \\
\text { funnel } \\
\text { Sec. }\end{array}$ & $\begin{array}{c}\text { Sp \% } \\
\text { wt. of } \\
\text { cement } \\
\text { per } \mathrm{m}^{3}\end{array}$ \\
\hline $\begin{array}{c}\text { SCC LP } \\
\text { SF }\end{array}$ & 680 & 7.34 & 1 & 12 & 8.7 \\
\hline $\begin{array}{c}\text { SCC LP } \\
\text { SF HR1 }\end{array}$ & 600 & 10 & 1 & 20 & 11.6 \\
\hline $\begin{array}{c}\text { SCC LP } \\
\text { SF HR2 }\end{array}$ & 700 & 4 & 1 & 16 & 12 \\
\hline
\end{tabular}

\section{Preparation of acid solution}

In the present work, chemical immersion tests were adopted in order to assess the resistance of SCC. All concrete specimens were cured in water for 28 days, after which they were immersed in acid solution. The initial $\mathrm{pH}$ (2.3) of the solution increased quickly. A digital portable $\mathrm{pH}$ meter was used for monitoring the $\mathrm{pH}$ levels of the sulfuric acid solutions. Specimens were fully immersed for 41 weeks, before chemical immersion, the concrete specimens were left to dry under room temperature. Each group of mixtures had its own acid bath. This is to provide similar acidic environments for the different binder mixtures in each group of mixtures.

\section{Harden concrete properties}

\subsection{Compressive strength of concrete}

Table 5. presents the result of compressive strength at 28 days for each concrete as well as the compressive strength of concrete cubes after 90, 182 and 289 days immersion in sulfuric acid solution. The 28 days compressive strength of each concrete is used as a criterion for comparison of the compressive strength of the cubes after immersion in the sulfuric acid solution. Fig. (1) shows the relative change of compressive strength against the immersion time upto 289 days for all concretes mixtures.

Table 5. Compressive strengths of concrete mixes

\begin{tabular}{|c|c|c|c|c|c|}
\hline & & $\begin{array}{c}\text { Compressive } \\
\text { strength } \\
\text { Mix } \\
\text { notation }\end{array}$ & Mix & No. & \multicolumn{3}{|c|}{$\begin{array}{c}\text { Compressive } \\
\text { 28 days before } \\
\text { immersion } \\
\text { impth }\end{array}$} & \multicolumn{2}{|c|}{ immerter } \\
\cline { 4 - 6 } & & $\begin{array}{c}90 \\
\text { days }\end{array}$ & $\begin{array}{c}182 \\
\text { days }\end{array}$ & $\begin{array}{c}289 \\
\text { days }\end{array}$ \\
\hline $\begin{array}{c}\text { SCC LP } \\
\text { SF }\end{array}$ & M1 & 69.0 & 41.5 & 53.0 & 44.1 \\
\hline $\begin{array}{c}\text { SCC LP } \\
\text { SF HR1 }\end{array}$ & M2 & 68.5 & 30.0 & 28.0 & 25.6 \\
\hline $\begin{array}{c}\text { SCC LP } \\
\text { SF HR2 }\end{array}$ & M3 & 67.5 & 45.0 & 45.5 & 35.6 \\
\hline
\end{tabular}

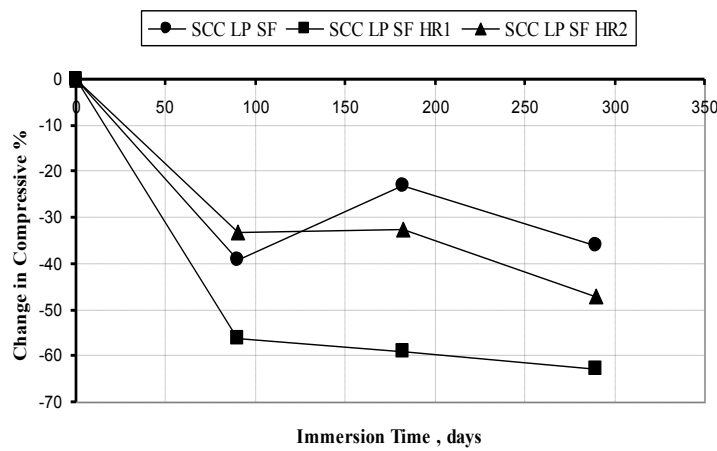

Fig1. The relative change in compressive strength after immersion in $\mathrm{H}_{2} \mathrm{SO}_{4}$ solution

From Fig (1), the relative change of compressive strength after 289 was $(36,62.6$ and 47) \% compressive strength loss for M1, M2 and M3, respectively. It was observed that at the age of 180 days some specimens exhibit loss of compressive strength as shown in SCC LP SF and SCCLPSF HR2 while in mixes SCCLPSFHR1 there was an increase in concrete compressive strength. The compressive strength loss at this stage probably due to the micro cracks occurs between the matrix content after the diffusion of sulfuric acid. The mass gain can be attributed to saturation of the specimens it was observed that the use of hybrid fibers was insignificant in reducing the concrete compressive strength loss, it may increase the voids in concrete matrix and this may cause further diffusion of sulfuric acid and result further corrosion of concrete that is exposed to sulfuric acid solution.

\subsection{Mass loss of concrete specimens}

Table 6 presents the result of density at 28 days for each concrete as well as the density of concrete cubes after 90, 182 and 289 days immersion in sulfuric acid solution. After immersion in $\mathrm{H}_{2} \mathrm{SO}_{4}$ solution, the relative change of mass against the immersion time up to 289 days was $(11.76,7.74$ and 7.8$) \%$ mass loss for M1, M2 and M3 respectively, as shown in Fig. 2.

Table 6. Mass loss of concrete samples

\begin{tabular}{|c|c|c|c|c|c|}
\hline \multirow{2}{*}{$\begin{array}{c}\text { Mix } \\
\text { notation }\end{array}$} & \multirow{2}{*}{$\begin{array}{l}\text { Mix } \\
\text { No. }\end{array}$} & \multirow{2}{*}{$\begin{array}{l}\text { Density of } \\
\text { concrete } \\
\text { specimens } \\
28 \text { days } \\
\text { before } \\
\text { immersion } \\
\left(\mathrm{kg} / \mathrm{m}^{3}\right)\end{array}$} & \multicolumn{3}{|c|}{$\begin{array}{l}\text { Density of concrete } \\
\text { specimens after } \\
\text { immersion } \\
\left(\mathrm{kg} / \mathrm{m}^{3}\right)\end{array}$} \\
\hline & & & $\begin{array}{c}90 \\
\text { days }\end{array}$ & $\begin{array}{c}182 \\
\text { days }\end{array}$ & $\begin{array}{l}289 \\
\text { days }\end{array}$ \\
\hline $\begin{array}{c}\text { SCC LP } \\
\text { SF }\end{array}$ & M1 & 2516 & 2535 & 2505 & 2220 \\
\hline $\begin{array}{l}\text { SCC LP } \\
\text { SF HR1 }\end{array}$ & M2 & 2577 & 2520 & 2545 & 2378 \\
\hline $\begin{array}{l}\text { SCC LP } \\
\text { SF HR2 }\end{array}$ & M3 & 2500 & 2385 & 2570 & 2305 \\
\hline
\end{tabular}




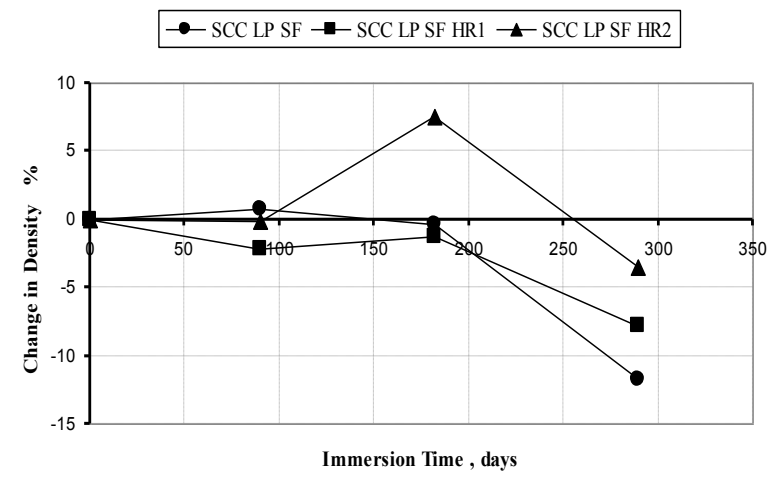

Fig 2.The relative change of density after immersion in $\mathrm{H}_{2} \mathrm{SO}_{4}$ solution

It was observed that at the age of 90 days some specimens exhibit loss of mass as shown in SCC LP SF HR1 and SCCLPSF HR2 while in mixes SCCLP SF there was an increase in concrete mass. The mass loss at this stage probably due to the micro cracks occurs between the matrix content after the diffusion of sulfuric acid. The mass gain can be attributed to saturation of the specimens or that is, in the initial conditioning age, the porosity in the concrete decreases which results in the mass increase. With continued exposure, most of the specimens exhibit mass loss. The reaction between sulfuric acid and the cement constituent of concrete results in the conversion of $\mathrm{Ca}(\mathrm{OH})_{2}$ to calcium sulfate (gypsum) which, in turn, may be converted to calcium sulfoaluminate (ettringite). Each of these reactions involves an increase in volume of the reacting solids by a factor of about two. The formation of calcium sulfate leads to softening (decrease in density) of the concrete. Since mass depends on both volume and density, the initial mass gain of the test specimens is probably due to the relative increase in volume being greater than the relative decrease in density [13]

\subsection{Splitting tensile strength of concrete specimens}

Table 7 shows the results of 28 day splitting tensile strength for all mixes as well as the splitting tensile strength of concrete specimen after 90,182 and 289 days immersion in sulfuric acid solution. From Table 7, the relative change of splitting tensile strength against the immersion time up to 289 days for M1, M2 and M3 was $(48,35$ and 35$) \%$ respectively, as shown in Fig. 3. With continued exposure, all of the specimens exhibit tensile strength loss. This was also observed by Fan et al [6]. At the end of the test (282 days), it was observed that the use of hybrid fibers in mixes (SCC LP SF HR1) and (SCC LP SF HR2) enhanced the resistance of SCC to sulfuric acid solution comparable with (SCC LP SF).
Table 7. Splitting tensile strengths of concrete samples

\begin{tabular}{|c|c|c|c|c|c|}
\hline & & $\begin{array}{c}\text { Splitting } \\
\text { tensile } \\
\text { strength }\end{array}$ & \multicolumn{3}{|c|}{$\begin{array}{c}\text { Splitting tensile } \\
\text { strength after } \\
\text { immersion }\end{array}$} \\
\cline { 4 - 6 } Mix & Mix & $\begin{array}{c}\text { MPa) } \\
\text { 28 days } \\
\text { before } \\
\text { no. }\end{array}$ & $\begin{array}{c}90 \\
\text { immersion } \\
\text { (MPa) }\end{array}$ & $\begin{array}{c}182 \\
\text { days }\end{array}$ & $\begin{array}{c}289 \\
\text { days } \\
\text { days }\end{array}$ \\
\hline $\begin{array}{c}\text { SCC LP } \\
\text { SF }\end{array}$ & M1 & 3.8 & 3.6 & 3.5 & 2 \\
\hline $\begin{array}{c}\text { SCC LP } \\
\text { SF HR1 }\end{array}$ & M2 & 4.3 & 3.9 & 3.3 & 2.8 \\
\hline $\begin{array}{c}\text { SCC LP } \\
\text { SF HR2 }\end{array}$ & M3 & 4.9 & 3.6 & 3.8 & 3.2 \\
\hline
\end{tabular}

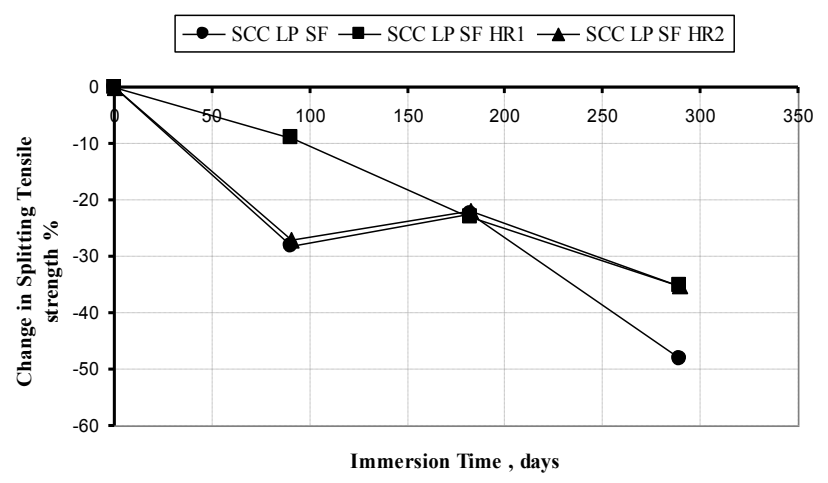

Fig 3.The relative change of splitting tensile strength after immersion in $\mathrm{H}_{2} \mathrm{SO}_{4}$ solution

\section{4 modulus of rupture of concrete specimens}

Table 8 shows the results of 28 day modulus of rupture for all mixes as well as the modulus of rupture of concrete specimen after 90, 182 and 289 days immersion in sulfuric acid solution. The relative change of modulus of rupture at 289 days comparable with result of 28 day modulus of rupture, was $(41,24$ and 25$) \%$ loss for M1, M2, and M3 respectively, as shown in Fig. 4.

Table 8 Modulus of rupture of concrete samples

\begin{tabular}{|c|c|c|c|c|c|}
\hline \multirow{2}{*}{$\begin{array}{c}\text { Mix } \\
\text { notation }\end{array}$} & \multirow{2}{*}{$\begin{array}{l}\text { Mix } \\
\text { no. }\end{array}$} & \multirow{2}{*}{$\begin{array}{l}\text { Modulus of } \\
\text { Rupture } \\
28 \text { days } \\
\text { before } \\
\text { immersion } \\
(\mathrm{MPa})\end{array}$} & \multicolumn{3}{|c|}{$\begin{array}{l}\text { Modulus of Rupture } \\
\text { after immersion } \\
(\mathrm{MPa})\end{array}$} \\
\hline & & & $\begin{array}{c}90 \\
\text { days }\end{array}$ & $\begin{array}{c}182 \\
\text { days }\end{array}$ & $\begin{array}{l}289 \\
\text { days }\end{array}$ \\
\hline $\begin{array}{c}\text { SCC LP } \\
\text { SF }\end{array}$ & M1 & 6.1 & 8.0 & 6.0 & 3.6 \\
\hline $\begin{array}{l}\text { SCC LP } \\
\text { SF HR1 }\end{array}$ & M2 & 6.6 & 6.5 & 7.5 & 5.0 \\
\hline $\begin{array}{l}\text { SCC LP } \\
\text { SF HR2 }\end{array}$ & M3 & 6.7 & 6.3 & 7.5 & 5.0 \\
\hline
\end{tabular}




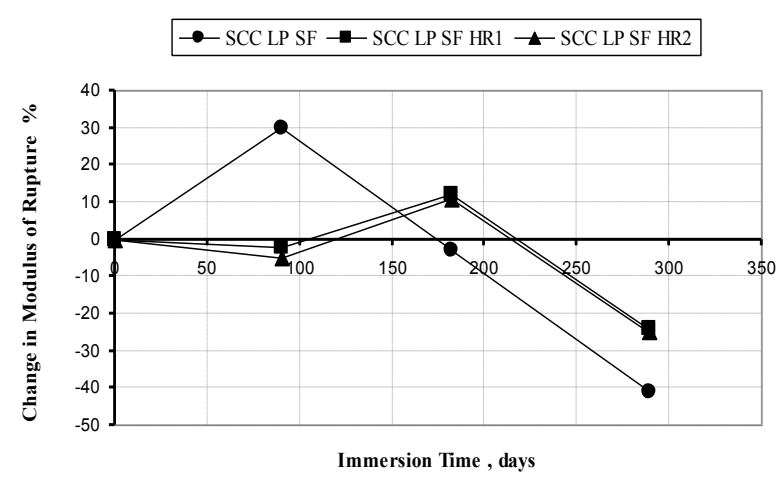

Fig4. The relative change of modulus of rupture after immersion in $\mathrm{H}_{2} \mathrm{SO}_{4}$ solution

After 90 and 182 days immersion in sulfuric acid solution some specimens exhibit decrease or increase in modulus of rupture. The decreases in modulus of rupture probably due to the micro cracks occur between the matrix content after the diffusion of sulfuric acid. The increases in modulus of rupture can be attributed to saturation of the specimens or reduction in porosity due to the chemical reaction between the sulfuric acid and the paste which results in increase in the modulus of rupture.

Finely, most of the specimens exhibit loss in modulus of rupture, at the end of the test (282 days); it was observed that the use of hybrid fibers affects the (fr) in the same manner as (ft).

\section{Conclusion}

After immersion in sulfuric acid solution. As a result, the following conclusions were obtained:

1. SCC concrete mixes were susceptible to sulfuric acid attacks but differed in the level of deterioration depending on the type of concrete mixes.

2. In the case of concrete specimens subjected to compressive strength load, the use of hybrid fibers in mixes M2 and M3 was insignificant in reducing the concrete compressive strength loss comparable with M1 the reduction was (62.6 and 47$) \%$ respectively while for $\mathrm{M} 1$, the reduction was (36)\%.

3. Concretes made with silica fume only have a higher mass loss comparable with M2 and M3 (specimens with hybrid fibers) the reduction was $(11.76) \%$ and for mixes with hybrid fibers the reduction was $(7.74$ and 7.8$) \%$ respectively.

4. In the case of concrete specimens subjected to tensile strength load the use of hybrid fibers in mixes M2 and M3, enhanced the resistance of SCC to sulfuric acid solution comparable with M1 the reduction in tensile strength was (35 and $35) \%$ respectively while for $\mathrm{M} 1$, the reduction in tensile strength was (48)\%.
5. It was observed that the use of hybrid fibers affects the modulus of rupture in the same manner as splitting tensile strength.

\section{References}

1. M.T. Bassuoni , and M. L. Nehdiet, Cement and Concrete Research 37 pp 1070-1084, (2007)

2. P. S. Sesha , S. T. Sehadri, R. Srinivasa, Sravana, P. Sarika, Volume: 02, Sep-(2013)

3. H.Siad, H. A. Mesbah , H. Khelafi , B. S. Kamali , and M. Mouli , Can. Journal in civil engineering, 37 pp 441- 449, (2010)

4. M.T. Bassuoni M. L. Nehdiet, and M. Amin , : Proceedings of the ICE - Construction Materials, Volume 160, August, PP 113-123, (2007)

5. Y.Senhadji, G. Escadeillas, M. Mouli, H. Khelafi , and Benosman, Powder Technology 254 314-323, (2014)

6. Y.F. Fan., Z.Q. Hu, and H.Y. Luan, Interaction and Multiscale Mechanics, Vol. 5, No. 1, pp.41-56, (2012)

7. S. A. Saleh , Z. A. Al -Din, and R. Z. Jasim, Eng .\&Tech. Journal,Vol.30 No . 11,pp.259 -272,( 2012)

8. ASTM C150, "Specification for Portland Cement" Annual Book of ASTM Standard, Vol. 04-02, (2002)

9. Iraqi Specification, No.5., "Portland cement".(1984)

10. ASTM C618-03, "Standard Specification for Coal Fly Ash and Raw or Calcined Natural Pozzolan for Use in Concrete", Annual Book of ASTM Standard, Vol. 04-02, February, p. 3. ( 2003)

11. EFNARC, "Specification and Guidelines for SelfCompacting Concrete", , February, pp.32 (2002)

12. Self-compacting concrete European project group, "The European Guidelines for Self-Compacting Concrete" May, pp 43-56,( 2005)

13.E. K. Attiogbe, and S. H. Rizkalla , ACI Materials Journal $I$ November-December PP: 481488,( 1988) 